\title{
Polskie wiersze okolicznościowe okresu rokoszu Zebrzydowskiego - problemy genologiczne
}

Teresa Banaś 


\section{Teresa Banaś}

\section{Polskie wiersze okolicznościowe okresu rokoszu Zebrzydowskiego - problemy genologiczne}

W iersze zebrane przez Jana Czubba w pierwszym tomic Pism politycanych z caasu rokoszu Zelrzydou'skiego 1606-1608' zostaly nazwane przez swego wydawce ,poezją rokoszową", przy czym przyporządkowanie kilkudziesięciu bardzo różnorodnym tekstom miana „poczji” uwarunkowanc zostalo wyłącznic ich rymowanym charakterem, nie zaś jakimś wyraźnym kryterium „poetyckości”. Omawiany tom zawiena sześćdziesiąt sześć ntworów o rozmaitej strukturze, dhıgości i kompozycji, a ich poziom artystyczny oceniany jest przez badaczy stabo ${ }^{3}$. Na ogół określa się te wiersze mianem „politycznej poezji okolicznościowej"t. Zaledwie kilka tekstów jest lacińskich, reszta to utwory polskic, pisane bądź wierszem stychicznym (najczęściej trzynastozgloskowcem o rymach przyległych $7+6$ aabb oraz jedemastozgloskowcem 5+6aabb), bądź zlożone strofami (przeważnie czterowersowymi) o róznorodnych formatach sylabicznych, wśród których nierzadko wystẹpuje strofa saficki. Mając

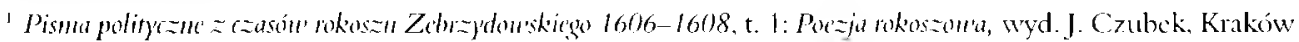
1916, s. $1-4(1) 4$

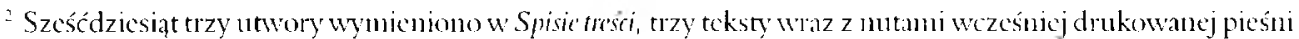
bojowcj unicścil wydawca w lizupehiemin tomu — ibidem, s. 357-384.

'Zob. S. Nicznanowski. I've'ja polityezm. hasto w: Stoumik literantrystaropulskiej. red. T. Michalowska, B. Otwi-

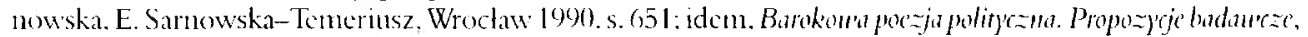

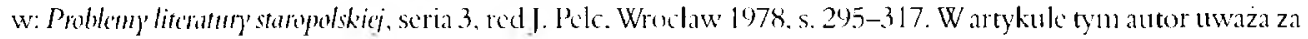
staropolska ,poczje polityczną" utwory o duzych walomal estetycznych. które maja clarakter uniwersalny i moga poruszyć wspólczesnego odbiorę̧. Takic wyınogi spclniają dziś - wedlug badacza - wyłącznic wybranc teksty Jana Kochanowskiego. Mikohaja Sępa-Szarzyńskicgo i Wespazjana Kochowskicgo (op. cit. s. 297).

"Termin .litcratura okolicznościowa” rozpowszechnil w badaniach historycznolitcrackich J. Nowak-Dlu-

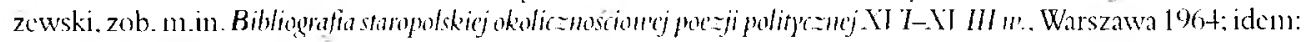

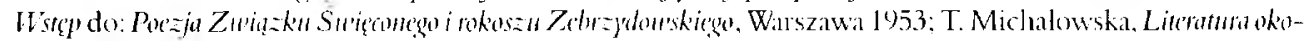

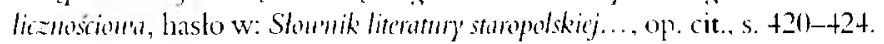


na uwadze staropolskie kryteria rodzajowości oparte na "sposobach naśladowania” (1. „naśladowanie" bezpośrednio przez poetę; 2. pośrednio - za pomoca postaci wprowadzonych przez autora; 3. sposób "mieszany”, gdzic wypowiadajł się zarówno postaci literackie, jak i sam autor), można zauważyć, ze w wielu rokoszowych wierszach wszystkie te trzy rodzaje wspólistnieja ze sobą (często w obrębic jednego tekstu).

Celem moim nic jest dogłçbna analiza genologiczna omawianych wierszy (bo tego niepodobna omówić w jednym referacie), ale ukazanic na wybranych przyktadach rozlegtego wachlarza form tak poetyckich, jak i publicystycznych, wspólistniejących nierzadko w ramach jednego tekstu. Wydaje się, że teoria gatunków i odnian znana byla autorom omawianych wierszy bardziej z lektury i immanentncj poetyki anizeli z uczonych wywodów autorów podręczników poczji czy wymowy, a praktyka pisarska - jak zaświadczają zresztą badania genologiczne - znacznie nieraz odbiega od spisanych w kompendiach poetyki i retoryki regutt.

Szczególne „pojemne” i otwarte na polączenia z innymi gatunkami są rokoszowe dialogi — i tak na przykład dialogowy utwór Jana Krajewskiego Zgoda i pokoij zawiera oprócz odmian s a t y r y c z 11 y c h, ganiącycl rokoszan, fragment paneg i y k u na cześć króla, elementy modlit wy do Boga idziękczynny ly y 11 na cześś Stwórcy. Natomiast rozległy tekst zatytukowany Tragedyja rokoszon'a nic jest w istocic rzeczy t r a ge d i a (jak by na to wskizywaba nazwa genologiczna w tytule), lecz d i a log i e m wiclu postaci, także alegorycznych i zbiorowych „stron” konfliktu, prezentujących sprzeczne racje. Tekst ten jest ciekawy chociazby z tego względı, że zawiera zaczątki dramatycznej akcji (czego nie obserwujemy w typowych dialogach). Utwór oddaje mianowicie przebieg obrad rokoszowych aż do wyboru deputatów, a poszczególne postaci demaskują się same poprzez charakter swych wypowiedzi". Brak momentu kulminacyjnego akcji oraz wyraźnego zakoníczenia uniemożliwia nazwanie tego tekstu ,tragedią" czy ogólniej — „dramatem”.

Najczęstszym celem większości rozpatrywanych wierszy jest napominanie, krytykowanic, ganienic, a czasem wyszydzanie politycznego przcciwnika (cojest znamicnne dla rozmaitych odmian s a ty ry), wielokrotnie też, na zasadzie kontrastu, uwzniośla się i wychwala czlonków oraz przywódców whasnego obozu politycznego (laudacja wszak stanowi istotę pa n e gi ry k 11). Panegiryk jako samoistna forma „czysta” (wymieniana w dawnych poety-

\footnotetext{
Por. T. Michalowska. Stamopolska roria genologicana. Wroctaw 1974. s. 48-73 i nast.; cadem, Rodzaj literadki;

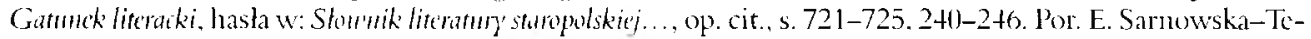

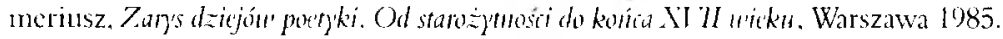

"Por. T. Michalowstis, Staropolska teria genologicana.... op. cit.. s. 156.

Pisma polityczme z a asóur rokoszu..., op. cit.. s. 349-356.

"Wide'n, s. $178-199$.

"W takim przypadku deprecjonuje autor osoby znanc z zycia publiczncgo poprzez przytaczanic w tekścic ich wypowiedzi, poddawanych ocenic czytchuika. Wzorcen tego rodzaju szyderczych dialogów byl - być moze

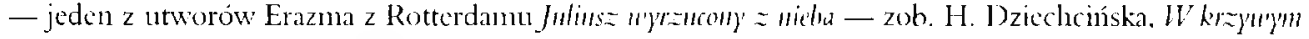

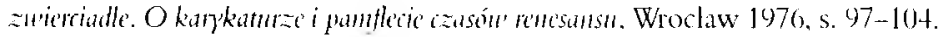


kach sformutıłowanych jako odmiana s y 1 wy $)^{111}$ wśród wierszy rokoszowych praktycznie się nie pojawia w formie samodzichnego tekstu laudacyjnego, łączy się natomiast często w obrębie jednego wiersza z innymi gatunkami.

Wcale nierzadko natrafiamy na agresywne formy satyry (dirae) zawicrajacc klątwy, ztorzeczenia, potępienia czynów określonej jednostki czy też zbiorowości (znamiennym przykladem moze byé zjadliwy atak na jezuitów w wierszu. Ad patres Jesu ${ }^{\prime \prime}$ ). Bywa, ze dirae wspólistnieją w jednym utworze z pancgirykiem na cześć wybitnej postaci i spontanicznym la m e $n$ te $m$ p o l i t y c z n y m (jak to ma na przyklad nniejsce w wierszu nieznanego autora Plankt na teraźniejsze nieszagshe (zas)' $\left.{ }^{12}\right)$.

Bodaj najwięcej utworów nawiązuje w swej strukturze do schematu retorycznego n a pom in an i a (w teoriach sformulowanych pojawiają się też inne nazwy tego gatunku: admonitio; protrepticum). Wśród czterech typów napominań wyszczególnionych przez Stefana Hermana na podstawie dawnych teorii wymowy, niemal wszystkie odmiany znaleźć można w poezji rokoszu Zebrzydowskiego ${ }^{1.3}$.

Bodaj najbardziej reprezentatywny przykład łagodnych przestróg i upomnicń typu admonitio ad parem ("do równych” mówcy), kicrowanych do "obywatcli koronnych" oraz rokoszan czy senatorów, znajdziemy w utworze Seweryna Bączalskiego Przestrach smientelmy't . Typ admonitio ab anctoritate et potestate, gdzie nadawca jawi się jako mentor i ,thumacz praw-

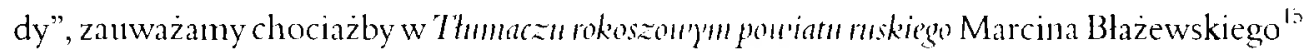
(w tym rozległym wicrszu napominanie wspótistnieje jednakże z imnymi gatunkami, wśród których najwyraźniej zaznaczają siç la ment poli ty c z u y i pobudka, inaczcjadhortatinum). W tomic poczji rokoszowej najtrudniej odnaleźc typ ndmonitio a commiscratione, gdzie napominający wyraża swoistą sympatię i wspókzucie do napominanego. Wydaje się jednak, ze ten typ wypowiedzi - kierowany do polskiego króla - dostrzec można w tekście Szymona Szymonowica Rytm po pogromienim ma teraźniejsze rozmdly (zwany też Lumią rokoszańską) ${ }^{16}$, aczkolwiek funkcjonuje w obrębie tegoż utworu jako .struktura wtrącona”. Lumia rokoszańska bowiem jako calość jest typową e le gios a t y r ą: łączy wszak w sobie harmonijnie fragmenty elegijne i satyryczne. Najlicznicjsze w tekstach rokoszowych sa jednakże admonitione's cum obinģatione - pisane w ostrym tonie, poniżajace osobę adresata i wykazujące szkodliwość występków regalistów, rokoszan bądź samego króla. Nie zawsze wszystkie części kompozycyjne, zalecane w retorykach dla admonitio - a zatem: cxordinm,

\footnotetext{
"Pancgiryk w poetykich dawnych wymicniany byl jako jeden z gatunków sy lw lub sytuowano go wobrçbic poezji epickicj (poesis cpica) - zob. T. Michatowska, Stropolska toria genologicana.... op. cit., s. 182.

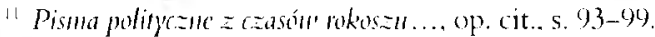

12 Ibideml.s. 7 l-75.

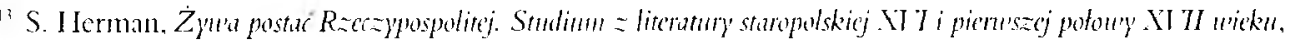
Ziclona Góra 1985, s. 167.

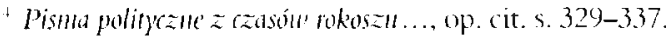

Is Ibidem. s. $156-177$.

"6 Jidcm, s. 315-322.
} 
marratio i epilogns ${ }^{17}$ - zostają w poszczególnych tekstach zachowane; czasem autorzy bez wstępu przechodzą do wyrażania upomnień i wyliczania zarzutów. Epilogus jednak, mający w założeniach teoretycznych zawierać krótka zachętę wejścia na dobrą drogę i uzasadnienie tejze zachęty, z reguly zostaje zachowany. Tak się rzecz przedstawia chó́by w anonimowym ataku na króla i jego doradców w wicrszu Sumnicuie món 'i ${ }^{1 \star}$ czy w ,paskwiliuszach” — Rata, rata, gore, gas! oraz Lciekaj, mickaj, bija!!".

Teksty mające w tytułacl stowa paskwil lub paskwiliusz oraz inne utwory niezawierające w tytule tej nazwy, ale o treści obelżywej, skierowanej imicnnie w stronę przeciwnika politycznego - nie maja jednolitej struktury. Nicktóre z nich, jak Pasku'illus o króln i radzie jego" mają formę dialogu, ośmieszającego określoną postać z życia publicznego (w tym konkretnym przykladzic jedna osoba zadaje pytanic, a druga podaje rzekomo „puuczającą" odpowiedź, która to odpowiedź deprecjonuje osobę króla), czasem osoby dialogu ośmieszają lub oskarzają się same poprzez treść własnych wywodów, jak w anonimowym utworze Dialogus"2. Bywa, ze inwektywy wyrazane są w formie narracyjnej, epigramatycznej, i dotyczą nie tylko konkretnej osoby, ale calej zbiorowości (jak w epigramach Poset na sejm; $\mathrm{Na}$ senator $\gamma^{2-2}$ ). Wydaje się. że ten typ epigramatycznych wypowiedzi stanowi kontynuację tradycji kąśliwych epigramatów Andrzeja Krzyckiego ${ }^{23}$.

Najczęściej jednak paszkwilowe fragmenty odnajdujemny w dhizszych formach narracyjnych, będących skrzyżowaniem (w ramach jednego tekstu) rozmaitych form satyrycznych, a także wierszowanych oracji.

Badacze rozpatruący literackie formy paszkwilowe z XVI wieku sklonn byli przychylac się ku twierdzeniu, ze w renesansie pa s z k w il pojmowano jako gatunek literacki, będący odmianą satyry lub epigram a tu. I Ianma Dziechcińska przyznała jednak, że juz w XVII stuleciu „deprecjacja bohatera zostala wpleciona w bogaty kontekst narracyjny i sytuacyjny" ${ }^{2+}$. Podane przykłady tekstów z okresu rokoszu Zebrzydowskiego zaświadczają, że już w pierwszym dzicsiçcioleciu XVII wieku w Polsce nic pojmowano paszkwilu jako gatunku literackiego o określonych regułach czy dominancie stylistycznej. Atak na konkretne osoby

\footnotetext{
7. Herman. $Z$ jutc postá $R=$ rizjpospolitej.... s. 167.

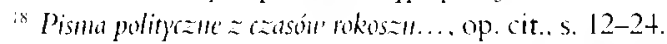

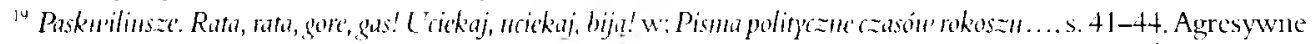
napominanic polączonc ze złorzeczenicm (diate) manny w ntworzc poświçconym hemanowi Zólkicwskic-

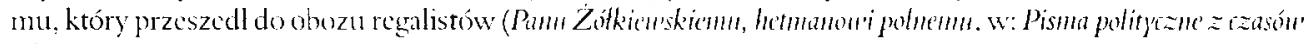
rokes $=11 .$. . op. cit. s. $65-67)$.

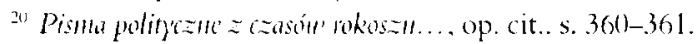

$\because$ Ibidem, s. 37-39).

Ibidem, s. 5,11 .

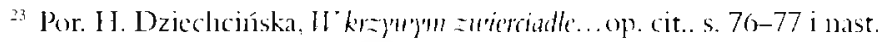

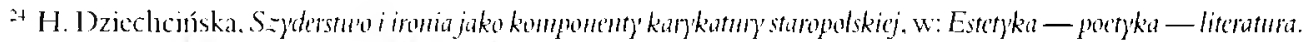

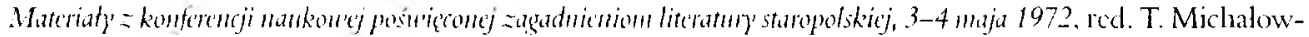

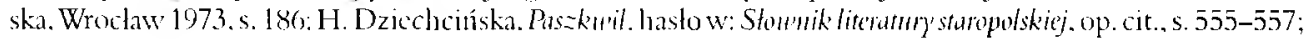

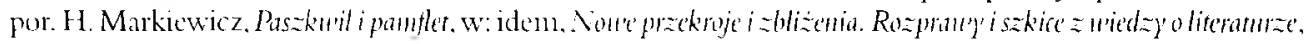
Warszawa 1974. s. $71-75$.
} 
mógl się bowiem przejawiać w różnych gatunkach poetyckich lub oratorskich: epigramacie, e chu (jako odmianie epigramatu), w rozmaitych odmianach satyry, a nawet w wierszowanych mowach. Paszkwil zaczęto zatem rozumić podobuie, jak definiują dziś pa $m$ flet wspólcześni nam teoretycy literatury: jako ..pozagatunkową kategorię organizacji publicystycznej i literackiej”, mogącą się realizować w róznorodnych formach genologicznych ${ }^{25}$.

Ciekawe, ze typowych form „sylwicznych”" w tomie poezji okresu rokoszu Zebrzydowskiego nie ma aż tak wiele. Wymieniany wśród sylw typ utworu o treści wyrażającej wdzięczność (eucharisticon) bądź wiersz o treści powitalnej (epibaterion - ten ostatni gatunek ujnowany niekiedy w teoriach jako odmiana endharisticom ${ }^{27}$ ) można polączyć z trzema zaledwie tekstami, napisanymi w tonacji podniosłej, nawiązı!jącymi do przyjazdu wojewody Zebrzydowskiegro na konwokację krakowską w celu pogodzenia się z królem. Są to mianowicie: Kaspra Miaskowskiego Post nebula Phoebus albo polska pogoda po burz' domoueje . St anishawa Grochowskiego Na dzien piatkou'y, któny by' szósty' miesiąa cann'a u' roku Panskim 1608. Do P. Mikotaja Ze-

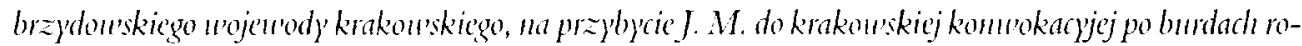
koszon'ydh ${ }^{29}$, a takze podpisany inicjalani A. W. wiersz Gratulatio na szczesślin'y przyjazd Jego M. Pana Wojewody Krakonskiego ma kommokacyja krakon'ska roku Paniskicgo $1608^{311}$. Wszystkie trzy wymienione dokonania twórcze łączą w sobie tréści pancgiryczne z treściami powitalnymi (epibaterion) i wyrażającymi wdzięczność (endharisticon). Post nelula Phoebus... Miaskowskiego zawiera ponadto (w drugiej części tekstu) ekspresywną po b u d kę p o l i y c z n ą do walki z wrogiem zewnętrznym, przy czym niemal caly schemat pobudki (omawianej w teoriach poezji i wymowy najczęścicj jako adhortatimum) zostaje zachowany. Sklada się nań: apostrofa do szlachty; zasygnalizowanie niebezpieczeństwa: przykłady niedbalstwa innych (tu: Greków i Węgrów), dalej - wezwanie do czynu; zapewnienic, że trudy się oplacą, i wreszcie odwolanie do honoru rycerskiego (tu - do tradycji „plemienia Piastowego") ${ }^{3 !}$. Tekstów tego rodzaju, realizujących wskazany schemat kompozycyjny pobudki, jest w omawianym tomie poezji rokoszowej sporo (Wyzmanie pran'dzin'yd araźn' szladicica polskiego; Elegia Koron)' Polskiej; Traba wolności; Korona polska barzo smuma prosby' serdeczne czyni niejakiego B. S. i wiele innych) ${ }^{32}$. Rzecz w tym, że schemat kompozycyjny pobudki też najczęściej nie występuje w for-

\footnotetext{
$\therefore$ Zob. H. Markicwicz. Paszonil i pantlit..., op. cit., s. 71-85.

36 W ostatnin czasie udowodnono, ze nicktóre teksty określane nianem . literatury okolicznościowej” maja istotny związek z poetyką sylw (kategoria nadgatunkowa obcjuntjaca szcreg form poctyckich). skodyfikowa-

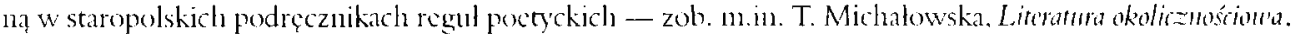

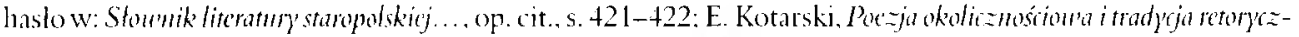

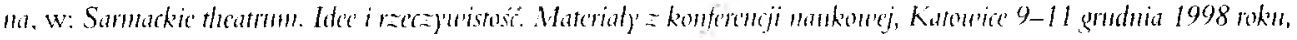
t. 2. red. R. Ocicczek przy wspóludz. M. Barkwskicj. Katowice 2001, s. 101-103 i nast.

27 T. Michalowsta, Staropolska teoria gendegic ama.... op. cit. s. 169.172

2* Pisma polityezm z czasón rokuszal. . op op. cit., s. 347-3+9.

Ibidcm, s. $340-3+7$.

in Ilidkm, s. 3+2-3+5.

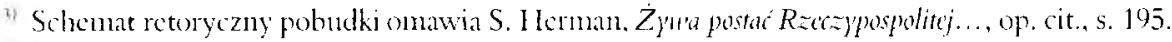

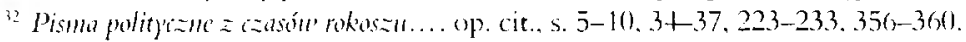


mie „czystej” (podobnie zresztajak panegiryk), ale w polączeniu zes ka rga, n a po mi na n ie mi innymi gatunkami ${ }^{33}$.

Od retorycznej pobudki odróżnić należaloby meliczną p i e śní b oj o w ą, której w obrębie „poezji rokoszowej” znalazły się dwa przykłady (Picśi nokoszanou animujacych się oraz Pieśn bojou'a rokoszan ${ }^{3+}$ ), gdzie zamiast sugestywnej perswazji sa podnioste apostrofy-wezwania, mające na celu podnieść na duchu rycerstwo przygotowujące się do walki. Pieśni te nie odwohują się do rozsądku i intelektu, lecz do emocji odbiorców. Cechuje je krótkość, ckspresywność, meliczność (do jednego z tekstów dołączone są nawet nuty), przy czym ekspresja oparta jest na eksklanacjach, enumeracjach i anaforycznej konstrukcji. Te wlaściwości formy zbliżają wskazane pieśni (nicodznaczające się wszakże wysokim poziomem artystycznym) do skodytikowanego w dawnych poetykach carmen lyricum ${ }^{35}$.

Inny omówiony u Horacego czy Juliusza Cesara Scaligera gatunek, ujmowany często w obrębie sylw, to epinicium (inne nazwy - cammen victoriae; carmen triumphale), definiowany jako tekst zawierający pochwał zwycięstwa ${ }^{36}$. Wśród rozpatrywanych wierszy są dwie niemal czyste realizacje tego gatunku - meliczne teksty o zwycięstwie regalistów pod Janowcem: Pieśn o rokoszu a. 1606 (ze wskazaniem pieśniowej melodii: „Nuta jako o Plocku”) oraz Dmiga pieśn o rokosie (z informacją: „Taż nuta, albo jako raczysz”). Najważniejsza w tego typu wypowiedziach poetyckich jest, jak twierdzil wiele lat po wydarzeniach politycznych z początków XVII stulecia Maciej Kazimierz Sarbicwski, ,pochwala zwycięstwa odniesionego nad wrogami, względnie dziękczynienie za zwycięstwo" ${ }^{37}$. Dnuga pieśni o rokosie... zawiera "wtopiony” w kontekst utworu fragment wierszowanej p i eśn i now in i a s s i e j-gatunku występującego wylącznie w literackiej praktyce.

Nawiązania do pieśni nowiniarskiej ${ }^{3 \sharp}$ istnieją zresztą też i w innych dokonaniach twórczych, między innymi w anonimowym, złożonym strofami czterowersowymi (o prostym, ośmiozgłoskowym formacie sylabicznym) R)tmice po pogromie ${ }^{39}$ (zaczynającym się od słów "Synowie Polskiej Korony, posłuchajcie tej nowiny..."), gdzie strukturami „wtrąconymi” funkcjonującymi w obrębic tekstu sł 1 a me 11 t polity czuy czy retoryczne admonitio

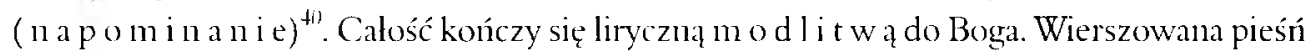
nowiniarska (z elementami politycznego lamentı, modlitwy oraz zawierającego przekleństwa i zlorzeczenia satyrycznego gatunku dirae) wydaje się także strukturą nadrzędną Pieśni

\footnotetext{
${ }^{3}$ I tak np. w utworze opatrzonym kryptonimen B. S. pobudka jest strukturą nadrzędną, ale tekst zawicraclementy naponinania (admonitio), lamentu politycznego i lanentu pogrzebowego - zob. Pisma polityczm' czasón rokoszll ..., op. cit., s. 22.3-23.3.

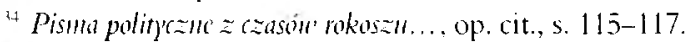

"Zob. nazwy i pojęcia camen lyricum, odt. odta. w: T. Michalowska. Staropolska teoria genologirzma ..., op. cit.,

s. $112-138,162.180-181$.

is Ilbide'm, s. 170.

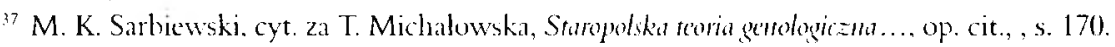

in O pieśni nowiniarskicj zob. m.in. J. Sokolski. Nominy, hasło w: Ston'mik literitury staropolskiej, op. cit.,

s. $512-514$ (tu też ua s. $51+$ - Iiteratura przedmiotu).

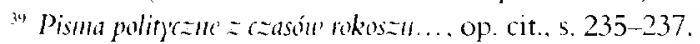

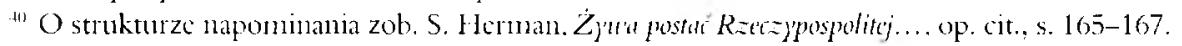


o rokos zu nieszczss $n y^{\prime \prime 1}$, autorstwa nieznanego rokoszanina. Lamentacyjny ton wsteppnej części utworu jest nicco mylący, wywód antora nie jest bowiem spontanicznym wyrazeniem żalu (jak to ma miejsce w lamencie), ale rzeczowym, stronniczym z d a n i e m r e l a cj i z wal ki, przy czym obrazowe pouczenie czytelnika o niecnych czynach regalistów zaświadczają, że zachowane zostaly dwie is totnc funkeje politycznej pieśni nowiniarskiej: funkcja informacyjna i dydaktyczno-propagandowa.

W omawianym tomie poezji odnaleźc można też wiersze, które w poctykach dawnych klasyfikowano w sposób niejednoznaczny i zróżnicowany: albo w obrębie poezji kunsztownej, albo epickiej, albo epigramatycznej. Man na uwadze kilka realizacji gatunku e clı a (Echo rokoszoue; Echo rokozanskic; Echo o rokoszu: Echo satobue ${ }^{+2}$ ). Jest to gatunek poetycki, w którym zazwyczaj na końcu każdego wersu pojawia się slowo lub zwrot rymujący się z wyrazem przedostatnim tegoż wersu, w wyniku czego powstają nowe, nieoczekiwane lub zaskakujące sensy $^{+3}$. W czasic rokoszı Zebrzydowskiego forma ta wykorzystywana byta często na użytek ganienia wroga politycznego (w tym także na uzytek paszkwilı), nickicdy tcż dla wyrażenia pochwaly sprzymicrzeńców politycznych.

W rozpatrywanym zbiorze wierszy, wydanym przez Jana Cizubka, mamy tylko jeden przypadek cancrimum - wiers za-raka, ujmowanego w poetykach wylącznie w obrębie poezji kunsztownej", a który czytany od końca daje sens odwrotny wobec tego, jaki wynika z odczytania wprost. Tekst ten - Na spran'y dzisiejsze polskit ${ }^{+5}$ - zawiera krytykę obyczajów rządzących, i napisany zapewne zostal pod wpływem słynnych Rakón' Jana Kochanowskiego, zawartych we Fraszkach czarnoleskich, o czym zaświadcza i styl, i stownictwo.

Niemało także — wśród omawianych dokonań twórczych - rymowanych form publicystycznych" ", wśród których dominuje wierszowana or a cja (nowa) i różne jej typy, jak wotum czy skarga (kwerela), dostrzegamy tez publicystyczny dialog. Teksty zatytułowane „wotum” lub „ekscytarz” sa po prostu wierszowanymi oracjami, wykorzystującyni środki perswazji i toposy występujące w mowie doradczej, oskarżycielskiej, ganiącej czy pochwalnej. Wynieńmy chociażby: Wotum Filopolita Prawdzickicgo, podhualajace i stwierdzajace Stou'a Inci Pan Stanistan'a Stadnickiego ze Zmigroda, starosty zygu'ultskiego, któremi się po-

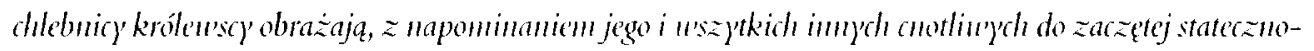
ści... ${ }^{+7}$, a takze Wotum zjazdóu i rokoszu 1606, od domatora jednego napisane $e^{\text {th }}$. Forma w ot u m (z lac. przyrzeczenie, ślubowanie, ządanie, przekleństwo) nawiązuje - jak wiadonno - do konwencji przemówienia sejmowegro, zawiera zalten cechy ślıbowania, deklaracji, doradza-

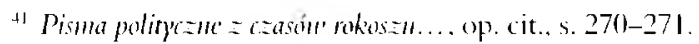

Iz Zob. ibidem, s. 39-40, 85-87. 88-89. Ostami utwór - Edh Edobme wtopiony jest w kontckst wicrsza Jana

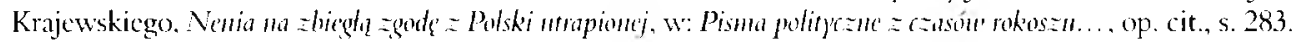

1. T. Michalowska. Staropolska terra genologicana,... op. cit. s. 167.

${ }^{+4}$ Ibidem, s. 161-162.

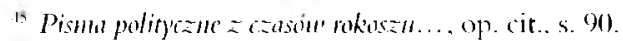

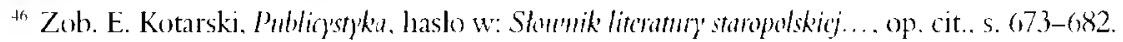

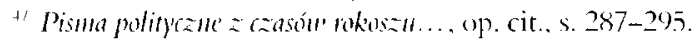

Ibide'm, s. 362-375. 
nia, odradzania, a nierzadko też osobiste refleksje i żądania ${ }^{{ }^{19}}$. Głównym celem „wotum” jest jednak „doradzanie” i „odradzanie”. Jeden z rozleglejszych tekstów, zatytułowany Ekscytarz, niemal w całości jest rymowaną mo w ą o s k a r ż y c i c l s ką. skicrowaną przez rokoszanina do króla Zygmunta III.

Serię wicrszowanych oracji ganiących konkretne postaci z życia politycznego (oraz jedną pochwalną - laudację biskupa Tylickiego) odnajdujemy chociażby w zapisanej trzynastozgloskowcen stychicznym Przemou'ie do Panow senatorow" ". Przedziwna to "przemowa” rokoszanina do szacownych osób - biskupów i senatorów, zawierająca wulgaryznny, inwektywy, obelgi. Obrażane są matki, żony, synowie poszczególnych senatorów, kwestionowane są ich rodowody szlacheckı. I tak na przyklad biskupa Baranowskiego zwie się ,baranem”, a biskupa Pstrokońskiego - ,ghupią szkapą". Perswazja przeważa w wierszowanych polemikach, będących na przyktad odpowiedziani na paszkwile, gdzie szczególnie rozbudowaną częścią komunikatu jest refutatio (jak u Miaskowskiego w: Apologia na pasknil; Pugna andabatarmm albo slepy pojedynek heret)ka z passyanem ${ }^{31}$ ).

Bardzo często wiersze rokoszowe mają w tytulach słowa "lament”, „plankt”, nenia”, sygnalizujące lączność z tradycją literacką la me n t u czy inaczej - t r e n u pol i t y c z n e go (w poetykach jako wzorcowy lament polityczny wskazywano wypowiedź biblijnego Jeremiasza) ${ }^{52}$, jednakże często tytuły te są mylące. Trzeba chyba zgodzić się z niektórymi ustaleniami badawczymi, które rozróżniaja poetykę lamentu od poetyki retorycznej s ka rg $\mathrm{i}^{53}$. W obydwu gatunkach podmioty mówiące (którymi są bądź patriota-syn Ojczyzny, bądź upersonifikowana Rzeczpospolital) „uskarżają się”, wyrażają narzekanie i żal, ale różnica polega nie tylko „ha wyższej tonacji uczuć" w lamencie. Równie istotny jest bezlad kompozycyjny w tym ostatnim (co eksponuje nieuporządkowany tok myśli lamentującego podmiotu), w skardze natomiast, wzorowanej na retoryce sądowej. mamy z reguly wyrazisty schemat kompozycyjny (najczęściej według wzoru: narratio, confimmatio, peroratio) ${ }^{55}$. Wydaje siç, że cechy gatunkowe skargi zawiera anonimowa Eleg̣ia Korony' Polskiej, aczkolwick oprócz poctyki skargi można w tym utworze, jak i w wielu jeszcze innych tekstach, zauważyć cechy znamienne dla napominania i pobudki. Wymicniona Elegia Koron) Polskiej $1606^{5 x}$, choć ma w tytule nazwę genologiczną e l c gi a, to zawiera słownictwo obelzzywe - jak zresztą szereg innych utworów rokoszowych - i z elegia jako gatunkiem poetyckim ma niewiele wspólnego. Przypomnijmy bowiem, ze teoretycy renesansu (Robortello, Minturno, Pontanus, Scaliger) postulowali dla

\footnotetext{
+4 Por. E. Kotarski, Publio'styka.... op. cit., s. 678 .

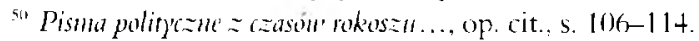

${ }^{51}$ Ibidem. S. 24. 29(-300).

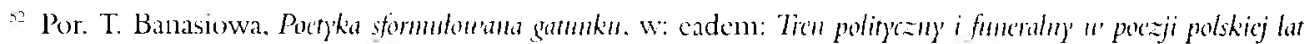
1580-16.30, Katowice 1997. s. 12-33 i nast.

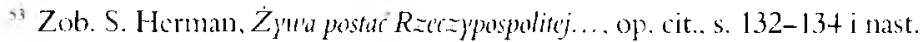

${ }^{54}$ Ibidem, s. 132.

"Ibidem. s. 134.

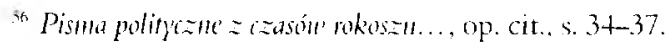


elegii styl wykwintuy, subtelny język i subiektywne ujęcie tematu ${ }^{57}$. Tak pojętych elegii w zestawie poezji rokoszowej brak (nimo owych mylących czasen odbiorcę tytulów).

Tre" politycz n y, rozmmiany w poetykach sformulowanych najczęściej jako odmiana twórczości elegijnej j’ , wśród tekstów rokoszowych także nie występuje w czystej postaci. W konkretnych utworach odnajdujemy jednak niejednokrotnie toposy ${ }^{\text {Sh }}$ i stownictwo znamienne dla trenów politycznych czy nawet trenow pogrzebowych, zdarzają siç tez cale zdania lub nawet dhuzsze frazy o charakterze lamentacyjnym. Wymieńmy chociazby takie wiersze jak: Jana Jurkowskiego Lech wzbudzony' i lanu'nt jego zatosny' "roku od jego panou'ania 1056 (utwór lączący w sobie cechy napominania, mowy doradczej, lanentu pogrzebowego i lamentu politycznego); Kaspra Miaskowskicgo Nenia na rozrnd donou' ', (tu lament polityczny wydaje się strukturą podrzędną wobec dominujących w tekście schematów pobudki i napominania); Jana Danieckiego Żalosne narzekanie Korony polskiej (gdzie tren polityczny wspólistnieje z napominaniem, modlitwa, satyrycznym gatınkicm dirae, a nawet z p oc m a tem opisow ym i a legorycz 1 y $m$ (many bowiem opis zamku, gdzie mieszkaja alegoryczne postaci). Niezwykle rozbudowany jest tekst Jana Krajewskiego Nenia na zbiegla zgo$d_{\mathfrak{q}}$ z Polski utrapionej ${ }^{\prime 3}$, składający się z wiclu fragmentów i będący „krzyzówką" szeregu różnych struktur gatunkowych: rozmaitych typów dialogu, a takze admonitio, struktury e mblematyczneji, modlitwy, lamentu politycznego, lamentu pogrzebowego, przy czym calośç kończy się Edhem ̇̇ałolmı'm.

Jak wynika z podanych przykładów, tragmenty lamentacyjnc pojawiają się głównic w tych utworach, które lączą w swej strukturze wiele gatunków. Najczęściej frazy lamentacyjne, wtopione w kontekst rozległych wypowiedzi na poły literackich, na poly publicystycznych, spehniają funkcję lirycznego ,argumentu”. Sięgnięcie wszakże po lament w funkcji chwytu retorycznego bylo jednym z charakterystycznych rysów dawnej kultury szlacheckicj" ${ }^{60}$. Lament zatem funkcjomuje jako ,argument” w obrębie napominania, pobudki, a także w różnych odmianach dialogu. Specyficzną rolę spełniają fragmenty lamentu pogrzebowego, informując o zblizającej się śmicrci ojczyzny i o bólı z tyın zwiazzanym — stanowią one ostrze-

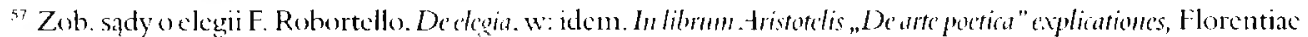
1548, s. 59-64; por. kompleksowe omówicnic teorii clegii w poctykach dawnych - T. Michalowska. Staropolska teoria semoloyiczlat..., op. cit., s. $1+1-1+7$.

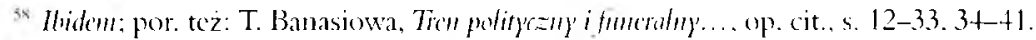

301 Toposem z trenów pogrzebowycl jest m.in. wzywanic przedniotów martwych lub ożywionych do oplakiwania zmartego. W tekstach rokoszowych kaze siç oplakiwać umicrajạca Matkẹ-Koronç Polską, por. up. frag-

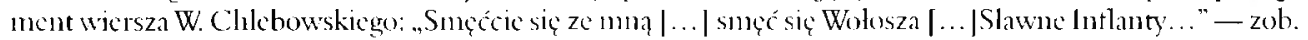

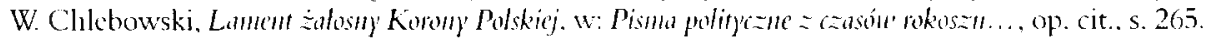

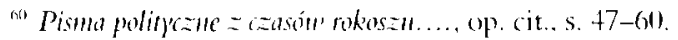

nl lidkm. s. ()(1)-62.

o. Ibidem, s. 131-147.

"Ibidem, s. 272-283.

th Jeden z fragmentów starodruku zawiera rycinç. mającą ohrazowác bitwę (iuzowską (w wydaniu Jana Czub-

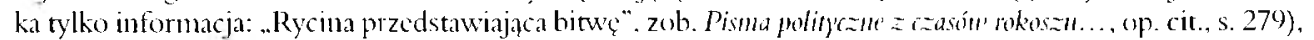
a niżej znajduje siç tekst bezpośrednio nawiązujący do przedstawioncj ilustracji.

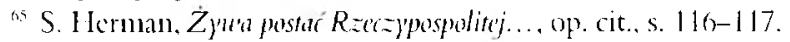


zenie przed upadkiem Polski i kierowane sa do rządzących. Bywa, że nawiązanie do lamentu (politycznego czy pogrzebowego) występı je jedynje w tytule, bądź stanowi drobny wtręt do wiersza mającego charakter zdecydowanie satyryczny, jak to siç przedstawia w anonimowym Lamencie ma sektę rokoszaniską... (w dalszej części rozbudowany tytul sam w sobie deprecjonuje rokoszan). W takim przypadku powaga literackicj konwencji (Biblia, Jeremiasz) niejako motywuje treści satyryczne, często o zacięciu paszkwilowyın.

Inaczej rzecz się przedstawia, gdy celem gtównym nadawcy jest zarówno wzruszenie odbiorcy losem kraju, jak i krytyka przeciwników, wyrażona za pomocą ganienia czy napominania. Wówczas obszerne partie lamentacyjne tekstu (o funkcji ekspresywno-impresywnej) nie tracą swej lirycznej tonacji i w danym tekście łączą się harmonijnie z równie rozległymi fragmentani satyrycznymi. W takim przypadku nożeny nówić o formie gatunkowej e l e g i o s a y $\mathrm{y}^{67}$. Tu lament funkcjonuje njejako na równych prawach z cząstkami satyrycznymi tekstu (nie jest strukturą podrzędną). Taki schemat budowy obserwujemy chociażby w wierszach anonimowych: Elegia postón' spladron'an $)^{\prime} h$ od pogan ${ }^{(i ⿱ 丷}, Z$ goda i zatosna przestroga ${ }^{\left({ }^{\prime \prime}\right.}$, a także w Rytmie po pogromieniu na teraźniejsze rozruchy' (I whni rokoszaniskiej) Szymona Szymonowica ${ }^{70}$ iw Trenie Rzeczypospoliteju' nieszazsne u'ojny donoure Kaspra Miaskowskiego ${ }^{71}$. W tym ostatnim utworze - w koricowej jego partii - many dodatkowe urozmaicenie struktury, gdyż w kontekst wiersza niejako wtopiony zostaje n a gr ob e k (epitafium) Ojczyzny, która wygłasza go sama, przewidując swój rychły koniec. Epitatium jako samodzielny utwór występuje w omawanym tomic wierszy tylko raz, i uwzniośla „rycerstwo polskie pobite pod Guzowem" "72.

W tomie poezji rokoszowej istnieje ponadto rozlegly poemat, nawiązujący w swej strukturze do funkcjonujących w literaturze staropolskiej poe ma tów a le gory cz ny c $\mathbf{h}^{73}$. Jest to obszerny, złożony z dziesięciu rymowanych rozdziałów, anonimowy utwór polskoję-

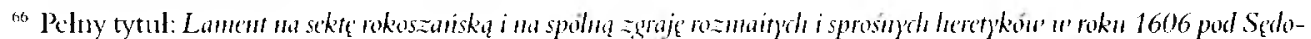

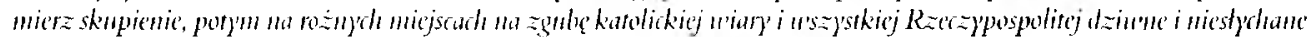

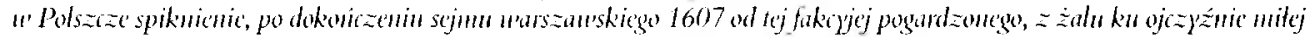

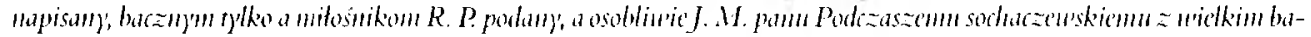

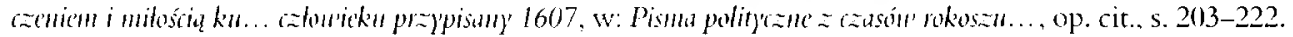

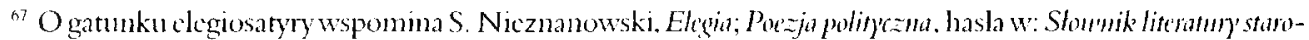

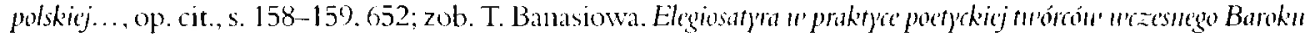

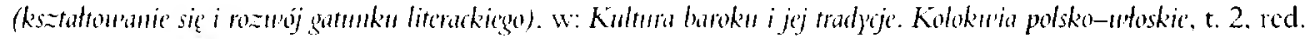

J. Malicki. P. Wilczek. Katowice 1994, s. 25-45.

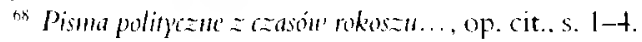

th' Hidem. s. 199-203.

${ }^{76}$ Ihidem, s. 315-322.

${ }^{71}$ Ibidkm. s. 310-314.

12 Samodziclne cpitafintm. stylizowanc - jak siç wydajc - na nagrobek bohaterów bitwy pod Tcrmopilami.

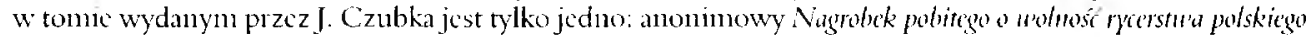

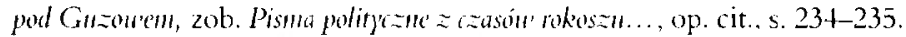

${ }^{73}$ Nicktóre z nich - jak wydawany wselckromic - w latach 1612. 1613, 1616, 1629- Hizernuk utrapionej Rzerzypospolity, drukowany pod nazwiskicm l'iotra Grzegorzkowica (wedlug Brucknera - pscudonim Jana Szczęsnego Herburta, wedlug Ludwiki Szczerbickicj-Slçk- pseudonim P’otra Cicklińskicgo), nawiązywaly do. Apocalipsis Jana Dymitra Solikowskiego z roku 1588. i mialy charakter rozlcglych nicraz epickich opowićści, w których boluatcrami litcrackimi byly fikcyjne postaci, alızyjuic nawiązujące do rzeczywistości. 
zyczny o lacińskinn tytule Et érunt nonisima peiora prioribus ${ }^{7+}$. Zawiera opowicść epicką o żeglarzu, który przyplynąl do nieznanego kraju, a błąkając się po lesie, zauważyl zanck, słabo strzezony przez strazee. Od tego momentu zaczyna się relacja o dzialaniach przedziwnych postaci — takze alegorycznych — w zamku i wokól zamku, co stanowi, jak zauważyl Jan Czubck, „alegoryczny obraz rokoszı Zebrzydowskicgo" ${ }^{75}$.

Co cickawe, wśród tekstów zebranych przez Jana Czubka odnajdujemy też i typowe gatunki liryczne, skodyfikowane w kompendiach poetyki: jeden z wierszy odwohuje się nawet do Horacjańskiej ody (pieśni $11+0$ natis, refer'nt in mare te not'i - Kaspra Miaskowskiego ntwór zaczynający się od słów Korabin Léchóm... $)^{7 n}$. Sygnatem nawiązania do poezji lirycznej i natchnionej są wcale nierzadko odwolania do toposu Muz czy do symbolu lutni, które zanważany na przyklad w poezjach rokoszowych Kaspra Miaskowskiego czy Szymona Szymonowica.

Wśród rozpatrywanych gatunków odnajdujemy też l i r y c z 11 c, nicbędące bynajmnicj parodiami, modlitwy i h y m n ic z n c pochwaly Stwórcy. Niemal „czystą" modlitwą (bez wtrętów innych form gatınkowych), zawierająca glównie prośby do Boga, Jezusa, Matki Boskiej, jest Piosnka nabożna za Króla Jego Mitośc i Rzeczpospolita Marcina Jarzębskiego ${ }^{77}$, wchodząca w sklad obszerniejszego cykłu utworów tegoż autora Na potomme czasy z placzem modli-

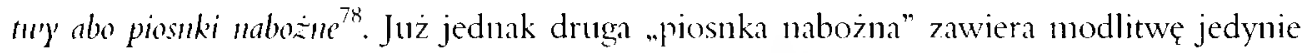
w picrwszcj części wiersza, w drugicj bowiem dominuja rady, pouczenia, napominania, naklanianic szlachty do zgody (jak w mowach doradczych i formach admonitio). Liczne liryczne fragnenty modlitewne zuajduja się ponadto w wiclu kontekstach satyrycznych.

I Iymniczne pochwaly Stwórcy zauważany rzadziej (głównie w formach rozbudowanych, lączących wicle gatunków naraz, jak w Lamencic zatosmym Korom) lolskicj Wawrzyńca Chlebowskiego $^{7 y}$ (tu elementy hymnu pochwalnego wtrącone zostaja w kontekst pobudki, gdzie zachęca się rycerstwo do walki z Tatarami) lub w dialogu Zgoda i poḱoj jana Krajewskiego, gdzie hynnem wyraża siç dziçkczynienie za odzyskany pokój i „domową zgodę”.

\footnotetext{
7." Pisma polityezhe z casóm rokoszll..... op. cit.. s. 238-255.

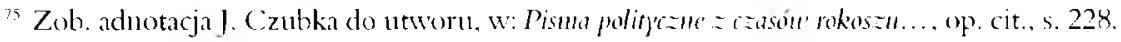

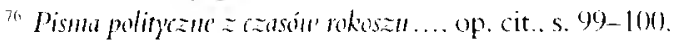

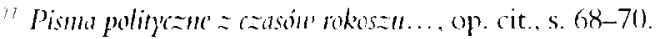

7 Mhidenl, s. 67-71.

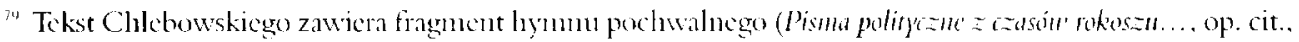
s. $2\left(0^{9}\right)$ :
}

\footnotetext{
Tobie wieloroczni Cherubinowic I szóstoskrzydlni con Serafinowic. Mocy i Sily, sluzą archancli
} l tèz anicli.

Stonce i miesiąc z zlotymi guviazdani $|\ldots|$

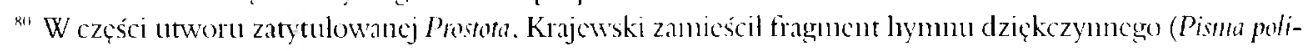

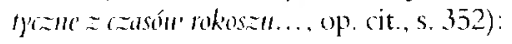


Zdarzaja się przeróbhi modlitwy (nieznanego autora Pacierz do króla jegomości ${ }^{81}$ ) i hymmu

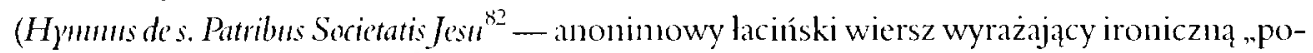
chwałę" jezuitów). Nie zostaje tu wyśmiana sanı struktura religijnych gatunków poetyckich, lecz osoby, do których komunikaty są kierowane (król, jezuici). Owe przeróbki poważnych utworów, dokonane w celach satyrycznych, w myśl zarówno dawnych teorii wymowy, jak i poetyk sformułowanych były odrębnymi formami gatunkowymi, definiowanymi jako p a rodi $e^{83}$. Obecnie pojęcie parodii rozumiemy inaczej: jako tekst ośmieszający inny tekst (a więc w grę wchodzą dwa komunikaty stowne, a nie kontekst pozaliteracki). W dzisiejszym rozumieniu wymienione utwory są zatem traw est a cja m i literackimi ${ }^{\text {st }}$.

Na koniec kilka uwag wypada poświęcić dwu osobliwym formom, funkcjomujacym

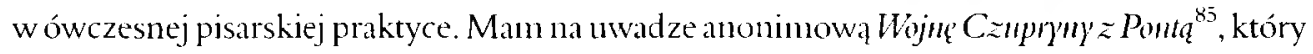
to wiersz można by nazwać - ıżywając terminologii Hanny Dzicchcińskicj — "literacką karykaturą" " Gówni bohaterowie rokoszu: król i Zebrzydowski przedstawieni są tu niczym tragikomiczne kukiełki i ośnieszeni z wykorzystaniem ironii literackiej, karykatury, groteski (wedlug Jana Czubka ukazano tu "rokosz oświetlony humorem i zanieniony w żart" ${ }^{\text {) }}$ ). Z kolei utwór drugi: Wyktad bogin stou'iniskich uesolego uidzenia stonica z pamma a' ztotym kole nad Krakourem Roku Panskiego 1608 Maja dnia 30 Marcina Paszkowskiego ${ }^{88}$ stanowi nawiązanie do

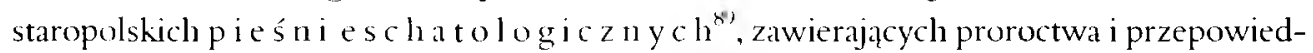
nie, które odnoszą się do historii grzesznej ludzkości, karanej cyklicznie przez zagniewanego

Przedwieczne Światlo. co rządzisz anioly:

Nicbo budowne masz w mocy. żywioly.

Tobie bądź chwala, ześ nas, lud ubogi.

Zbawil juz trwogi.

Zbawileś strachu, placzu żalosnego $|\ldots|$

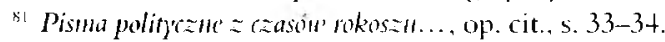

8 Ibidem. s. $91-93$.

${ }^{*}$ W antycznych i renesansowych podreçanikach poezji i wymowy parodiç rozumiano jako specyficzny gatunek (wspominany m.in. przez Arystotelesa, Kwintyliana, Scaligera, Juvencinsa), definiowany jako „wiersz napisany na podobieństwo innego: wszelkie naśladownictwo danego, ściśle określonego tekstu” — zob. T. Michatowska, Staropolska teoria genologicna..., op. cit., s. 183; por. H. Dzicchcinska, Parodia, haslo w: Ston'mik literatur' staropolskicj..., op. cit.. s. $552-5 \overline{5}+$.

st Trawestacja dzıs - to odwzorowanic schematu kompozycyjo-stylistycznego przy zmianic treści lub odwzorowanic toku fabulanego przy zmianic realiów i stylu: zob. H. Markicw icz, Parodia a imme gatmmki literadkie

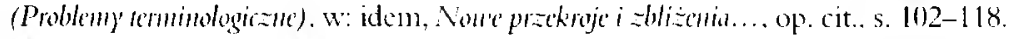

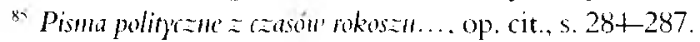

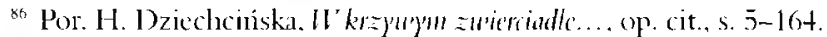

s7 Zob. adnotację J. C.zubka do wicrsza, w: Pisma polityente z casóm rokoszu.... op. cit., s. $28+$.

${ }^{8 x}$ Pisma polityante $\approx$ casóm rokos $\approx 11$.... op. cit., s. 337-3+2.

${ }^{84}$ Do tego typu utworów staropolskich zaliczylibyśmy chociażby anonimowy utwór Noura pieśn sad $\left.B_{0} \dot{z}\right)^{\prime}$ blisko

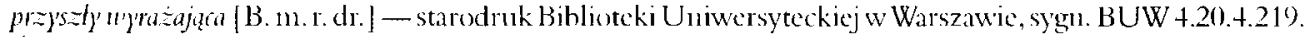
Ówcześnie murt twórczości .eschatologicznej” - wierszowancj i prozatorskicj - nie jest niczymodosobnionyn w piśmicnnictwic polskim; to nurt ogólnocuropejski - zob. J. Delumeau. Strach w kulturze Zachedu

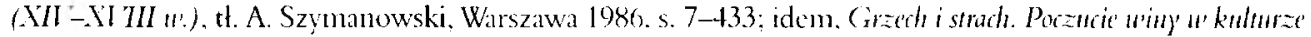
Zuchodi .MIII-. II $I I I$ w. tl. A. Szymanowski, Warszawa 1944. s. 5-791. 
Boga przeróżnymi plagami. Jedną z plag jest wlaśnic ..wojna domowa”. Ten nurt twórczości micści siç w granicach szeroko rozımiancj staropolskiej . paraliteratury" (podobnie jak niektóre wierszowance 11 ow i 11 y).

Po zestawieniu różnorodnych realizacji gatunkowych w poszczególnych dokonaniach twórczych poezji rokoszowej nasuwa się kilka wniosków.

Niezwykle rzadko mamy tu do czynienia z „czystymi” realizacjami gatunków w konkretnych tekstach. Większość wierszy to istna plątanina form literackich, paraliterackich, publicystycznych, oratorskich. Przy określaniu gatunkơw nie należy sugerować się tytutem, bo ten często bywa mylący. Najwięcej jest długich (liczących nicraz po kilkaset wersów) utworów o nicuporządkowancj kompozycji, z licznymi dygresjami, łączącymi w sobie - czasem w sposób zaskakujący — bardzo odlegke od sicbic tradycje genologiczne. Nawet jeśli w danym tekście jest tylko jeden podmiot mówiący, to zdarza się, że tonacja jego wypowiedzi zmienia się kilkakrotnie. Sytuacja komplikıje się jeszcze bardziej, kiedy w utworze wystẹpuje więcej podniotów mówiących: wówczas w obrẹbie tekstu przeplatają się nie tylko struktury gatunkowe, ale nierzadkoi „rodzajowe” (czyli — wedlug kryteriów staropolskich — rozmaite „sposoby naśladowania”).

Wydaje się, że tak bogata „instrumentacja gatunkowa” nie wynika tylko i wylącznie z gorących potrzeb ówczesnego "gwaltownego nutu życia politycznego" i jeden utwór miał spehnać wtedy "wiele funkcji naraz" . Można chyba zaryzykować stwierdzenie, ze wiersze rokoszowe z picrwszego dziesięciolecia XVII wicku są nicjako modelowym przykladem tego, co działo się w poezji polskiej u progu dojrzalego baroku. Krótkich i zwięzłych form poetyckich jest niewiele, a zwarta struktura tekstów nicjako rozsadzana jest przez dygresje, nagle zmiany wątków i „sposobów naśladowania”. Powoduje to powiçkszanie siç rozmiarów utworów, brak spójności w wielu z nich, a czasem też brak jednolitego, logicznego toku wywodu. Częste jest falowanie tonacji: lirycznej, epickiej, moralizatorsko-dydaktycznej.

W potocznej świadomości tak zwana „literatura okolicznościowa”, także ta o charakterze politycznym - to przede wszystkin różne odmiany sylw. Tymczasem poezja rokoszu Zebrzydowskiego daje znacznic bogatszy zestaw form genologicznych, z których część zostaha skodyfikowana w dawnych teoriach poezji lub wynnowy, a część funkcjonowala na zasadzie konwencji - tylko w pisarskiej praktyce. Badanie takich utworów wymaga nic tylko konfrontacji z obyczajami, polityka, kulturą czasów, w jakich teksty te powstawaly. Konieczne staje się czasem sięguięcie do metod poetyki opisowej (przy rozpatrywaniu form funkcjonujących wylącznic w pisarskicj praktyce); przy analizie i interpretacji często niezbędne jest odwoływanie się do dawnych regul teorii retorycznych, a takze — w miarç potrzeby - do regul poctyki sformulowanej. Materiał taki wymaga zatem „eklektycznycl" metod postępowania badawczego.

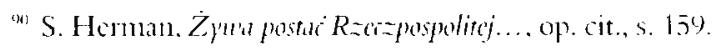

